(c) American Dairy Science Association, 2002.

\title{
Responses to Tail Docking in Calves and Heifers
}

\author{
D. A. Schreiner and P. L. Ruegg \\ Department of Dairy Science, \\ University of Wisconsin, Madison 53706
}

\section{ABSTRACT}

The primary objective of this study was to determine the behavioral and physiological effects of tail banding and atrophy using rubber rings 2 to 4 mo before first parturition in dairy heifers either with or without the use of epidural anesthesia. The secondary objective was to determine behavioral responses to tail banding using rubber rings in calves 7 to $42 \mathrm{~d}$ of age. Preparturient heifers $(n=24)$ were randomly assigned to one of four treatment groups: 1) tails were cleaned and handled; 2) tails were cleaned, handled, and an elastrator band was applied to the tail; 3) an epidural was administered 15 min before cleaning and handling; and 4) an epidural was administered 15 min before application of an elastrator band. Behavioral observations and physiological responses were collected for 6 wk. Additionally, behavioral responses to tail banding were recorded for $10 \mathrm{~d}$ on Holstein heifer calves that were 1 to 6 wk of age $(n=40)$. No significant differences in behavior were observed among treatment groups of preparturient heifers at any time during the 6 -wk observation period. Preweaned calves that were 21 to $42 \mathrm{~d}$ of age demonstrated significantly more restlessness after application of tail bands compared to younger calves or control calves of the same age. Plasma cortisol values of preparturient heifers remained within limits previously described for nonstressed animals and no significant differences were detected among groups. Hematological values remained within the reference values for cattle, and there were no significant differences between groups except for relatively more eosinophils in the heifers that received epidurals. No significant differences in heart rate or body temperature were detected among groups.

(Key words: behavior, dairy cows, stress, tail docking)

Abbreviation key: $\mathbf{C}=$ control, $\mathbf{C E}=$ control plus epidural, $\mathbf{D}=$ dock, $\mathbf{D E}=$ dock plus epidural, $\mathbf{O P W C}=$ older preweaned calves, $\mathbf{P P H}=$ preparturient heifers, $\mathbf{P W C}=$ preweaned calves, YPWC $=$ young preweaned calves.

Received March 11, 2002.

Accepted June 24, 2002.

Corresponding author: P. L. Ruegg; e-mail: plruegg@wisc.edu.

\section{INTRODUCTION}

Assuring the well being of animals is an increasingly important issue for the dairy industry. Management practices such as dehorning, branding, and tail docking are under increased scrutiny by the public (Swanson, 1995; Matthews, 1996; Stull et al., 2002). There are no apparent health benefits for cows that can be attributed to tail docking (Schreiner and Ruegg, 2002; Tucker et al., 2001). Some have expressed concern that tail removal will cause stress because the procedure may reduce cows' ability to control flies (Eicher et al., 2001; Hemsworth et al., 1995; Phipps et al., 1995). Many dairy farmers utilize tail docking because they believe it improves milking hygiene and the comfort of the milking personnel (Johnson, 1991; McCrory, 1976). On commercial dairy farms in the United States, tails are commonly removed one month before first parturition (20 to 25 mo of age) or coincident with dehorning of calves at 3 to 4 wk of age. Few studies have been conducted to determine the behavioral and physiological effects of tail docking in dairy cattle (Eicher et al., 2000; Petrie et al., 1995; Tom et al., 2002), and the differences in responses that may be attributable to age are unknown.

Variable responses to tail docking have been reported for lambs based upon their age and the type of docking procedure applied. Graham et al. (1997) compared behavioral and adrenal responses of lambs that were docked using rubber rings, crushing (using burdizzo) combined with rubber rings, or searing using a docking iron. The greatest adrenal and behavioral responses were observed in the animals that were docked with rubber rings compared to the other groups. The authors observed that the lambs that were docked using only rubber rings spent significantly more time in abnormal postures. Cortisol concentrations of lambs in the group docked using only rubber rings were at least $30 \mathrm{nmol} /$ $\mathrm{L}$ greater than the cortisol concentrations of lambs that received the other treatments. Kent et al. (1995) likewise reported an increased frequency of behaviors such as foot stamping, abnormal posture, and restlessness in lambs docked and castrated using rubber rings as compared to lambs that received treatments that included crushing (using burdizzo). Dinnis et al. (1997), compared responses of 45 - to 55 -d-old lambs to a variety 
of potentially stressful management procedures. Treatments included castration using rubber rings, tail docking using rubber rings, rubber ring and castration clamps combined with tail docking, rubber ring and clamp castration, and rubber ring docking. Comparatively low levels of distress were reported for tail docking using a rubber ring when it was not accompanied by castration.

Researchers have examined immediate responses to tail banding in 3- to 4-mo-old dairy calves (Petrie et al., 1995). Tail shaking was detected in 10 of the 15 banded calves during the first 30-min period after treatment, and the use of local anesthesia before docking inhibited all behavioral responses for approximately $2.5 \mathrm{~h}$. The authors concluded that tail docking with rubber rings elicited a behavioral response, but not enough to cause a significant difference in normal feeding and ruminating behaviors (Petrie et al., 1995).

The application of rubber rings in 7- to 17-d-old Holstein calves increased the frequency of tail grooming for up to five $d$ after treatment and resulted in modest changes in standing and lying behavior on the day of treatment (Tom et al., 2002). Plasma cortisol concentrations obtained $60 \mathrm{~min}$ after treatment were significantly higher in calves that received rubber rings compared to the control group, but no differences in milk intake, weight gain, body temperature, or fecal score were found.

Eicher et al. (2000), examined short-term behavioral, immunological, and endocrine responses to banding with and without local anesthesia using primiparous heifers. Twenty-one animals were observed for $24 \mathrm{~h}$ before and after the application of elastrator bands to tails. Four days later, the animals were monitored for $24 \mathrm{~h}$ before and after removal of the tail. The authors concluded that tail banding did not significantly affect cortisol or immune measures, but docked heifers were observed to spend more time eating after banding and less time eating after removal of the tail compared to control heifers (Eicher et al., 2000). Whereas there is a limited amount of research about immediate and shortterm responses to the application of bands to tails, the behavioral and physiological effects of the process of tail atrophy have not been reported. An acute inflammatory response or chronic stress may result in alterations in the hemogram and leukogram. The primary objective of this study was to determine the behavioral and physiological effects of tail banding and atrophy using rubber rings 1 mo before first parturition in dairy heifers both with and without the use of epidural anesthesia. The secondary objective was to determine behavioral responses to tail banding using rubber rings in calves 7 to $42 \mathrm{~d}$ of age.

\section{MATERIALS AND METHODS}

\section{Preparturient Heifers (PPH)}

Animals. Twenty-four nonlactating Holstein heifers, aged 20 to 25 mo, were used for this study. All heifers were pregnant and approximately 2 to 4 mo prepartum at the beginning of the study. Animals were housed together in an area that included a covered bedding pack (approximately $18 \times 14 \mathrm{~m}$ ), an outside cement lot (approximately $18 \times 30 \mathrm{~m}$ ), and an indoor alley (approximately $18 \times 6 \mathrm{~m}$ ) that included the feeding area and was accessed through an open doorway. The animals were fed an appropriately balanced TMR that was mixed and offered once daily. The TMR was available at all times and accessed through headlocks. When restraint was required, selected animals were herded into the indoor alley and a small amount of corn grain was offered to encourage the animals to enter the headlocks. The process of restraining the animals generally required about 20 to $30 \mathrm{~min}$, and animals were allowed to acclimate to restraint for an additional 15 to $20 \mathrm{~min}$ before handling. Animals were handled according to the recommendations and procedures approved by the Research Animal Resources Center of the UW-Madison (RARC \# A-07-3400-A00976-3-12-99). Animals were preconditioned by restraint and handling once daily for $5 \mathrm{~d}$ before the application of the treatments. Tails were cleaned with currycombs and clipped to remove tail hairs $2 \mathrm{~d}$ before the observation period to eliminate bias caused by hair loss between treatments. All animals received a clostridial vaccine (Bar Vac $\mathrm{CD} / \mathrm{T}$, Boehringer Ingelheim, St. Joseph, MO) 21 d before treatment.

Treatments. Animals were randomly assigned to treatment groups using a computer-generated table of random numbers. Treatments groups were: 1) control (C), tails cleaned and handled; 2) rubber ring dock (D), tails cleaned, handled, and an elastrator band applied to the tail 7.6 to $10.2 \mathrm{~cm}$ below the vulva; 3) $\mathrm{C}$ with an epidural $(\mathbf{C E})$, the dorsal sacrum was cleaned and scrubbed and an epidural (5 $\mathrm{ml} 2 \%$ lidocaine hydrochloride) was administered between the first and second coccygeal vertebrae 15 min before cleaning and handling; and 4) D with an epidural (DE), the dorsal sacrum was cleaned and scrubbed and an epidural was administered between the first and second coccygeal vertebrae 15 min before application of an elastrator band 7.6 to $10.2 \mathrm{~cm}$ below the vulva. Atrophied tails were allowed to fall off without assistance until $42 \mathrm{~d}$ post-treatment, at which time, any remaining atrophied tails (7 of 12) were removed.

Behavioral observations. All behavioral observations on the day of treatment were obtained by one of five trained individuals using a standard recording 
Table 1. Behavioral definitions for preparturient heifers (PPH) and preweaned calves (PWC).

\begin{tabular}{|c|c|c|}
\hline Behavior & $\begin{array}{l}\text { Group } \\
\text { recorded }\end{array}$ & Description \\
\hline Eat & Both & Head facing feed bunk, chewing or gathering feed \\
\hline Ruminate & $\mathrm{PPH}$ & Animal regurgitating feed, chewing, then swallowing cud \\
\hline Stand & Both & Animal in standing position not moving \\
\hline Walk & Both & Animal walking without signs of stiffness or arched back \\
\hline Tail shake & Both & $\begin{array}{l}\text { Intermittent and vigorous swinging of tail without tail } \\
\text { slapping back to indicate fly avoidance }\end{array}$ \\
\hline Vocalization & Both & Any vocalization by animal \\
\hline Foot stamp & Both & $\begin{array}{l}\text { Animal raising then forcefully lowering leg onto ground } \\
\text { resulting in shifting of ground not associated with } \\
\text { normal walking }\end{array}$ \\
\hline Grind teeth & $\mathrm{PPH}$ & $\begin{array}{l}\text { Animal's jaw is in motion in closed position and not in the } \\
\text { process of rumination }\end{array}$ \\
\hline Posture & Both & $\begin{array}{l}\text { Noted whether animal was standing with back straight, standing } \\
\text { with an arched back, lying sternal, or lying laterally }\end{array}$ \\
\hline Restlessness & $\mathrm{PPH}$ & $\begin{array}{l}\text { Animal constantly shifting weight between right and left } \\
\text { legs in standing position }\end{array}$ \\
\hline Restlessness & PWC & Number of times animal stood up or lay down every $15 \mathrm{~min}$ \\
\hline Tail tuck & Both & Tail drawn in tightly against body \\
\hline Rear visualization & PWC & Animal looking back toward rear quarters and tail \\
\hline Stiffness & PWC & $\begin{array}{l}\text { Animal standing without occasional body movement or } \\
\text { head movement }\end{array}$ \\
\hline Playing & PWC & Prancing, jumping, or running \\
\hline
\end{tabular}

form. Consistency among observers was verified before commencement of the experiment. On the day of treatment, behaviors were observed for individual heifers five times before the application of the rubber rings (-60, $-45,-30,-15$, and $-1 \mathrm{~min}$ ), every $5 \mathrm{~min}$ for the first hour post-treatment, every 15 min during hours 2 to 4 , and then every 30 min during hours 5 to 12 . Investigators took additional behavioral observations at 2400,0800 , and $1600 \mathrm{~h}$ each day for wk 1 and 2; at 0800 and $1600 \mathrm{~h}$ on wk 3 and 4 ; and, once daily, alternating from 0800 and $1600 \mathrm{~h}$, during wk 5 and 6 . Animals were restrained in headlocks for the first $4 \mathrm{~h}$ of the study ( $1 \mathrm{~h}$ before application of bands to $3 \mathrm{~h}$ after application of bands) on the day of treatment. All observations during this period were scan observations recorded on all animals throughout the entire observation period. Observers were within $3 \mathrm{~m}$ of the cows during this period. Observations taken after $4 \mathrm{~h}$ on the day of treatment were scan observations recorded while the animals were free to move about their environment. Defined behaviors that occurred during the period of observation were noted for each animal (Table 1). Observations obtained after the first day were scan observations recorded during a 30-min observation period before animals were restrained or handled. Observers recorded behaviors from approximately 4 to $9 \mathrm{~m}$ away from the animals. Behavioral observations were discontinued $4 \mathrm{~d}$ after atrophied tails detached or were manually removed.

Physiological and immunological measures. After behavioral observations were collected each day, animals were restrained in headlocks and allowed time to calm before obtaining heart rates and temperatures. On the day of treatment, heart rate and temperature were manually collected for each animal before collecting blood samples. When required, blood samples were collected immediately after the $0800 \mathrm{~h}$ observation period for the remainder of the study. After the first day, the process of collecting physiological data for all animals took approximately $1 \mathrm{~h}$.

Blood samples ( $15 \mathrm{ml})$ were obtained in sterile evacuated tubes by venipuncture from either the jugular vein at $-45,-15$, and -1 min before application of tail bands, and $15,30,60,90,120,180,240,360$, and $720 \mathrm{~min}$ after application of tail bands. Animals were restrained for blood samples collection. Blood samples for cortisol analysis were refrigerated, centrifuged, and plasma was separated within $5 \mathrm{~h}$ of collection. Additional blood samples $(15 \mathrm{ml})$ were obtained in evacuated tubes containing EDTA at -45 min before treatment and after the morning observation period on $\mathrm{d} 4,14$, and 21 . Hematological analysis was performed by Marshfield Laboratories Veterinary Diagnostic Services (Marshfield, WI).

Cortisol analysis. Blood was centrifuged and plasma was aspirated and stored at $-20^{\circ} \mathrm{C}$ for later analysis of cortisol. Samples were double-extracted using diethyl ether and snap freezing. Cortisol was resuspended in an ELISA assay buffer. A secondary antimouse antibody (Calbiochem, La Jolla, CA) with coating buffer was applied to a reader plate and was refrigerated at $4^{\circ} \mathrm{C}$ overnight. Excess secondary antibody was removed and a primary monoclonal cortisol antibody (Calbiochem, La Jolla, CA) was added and incubated 
for $1.5 \mathrm{~h}$ at room temperature. Excess primary antibody was removed and cortisol samples and standard curve samples were applied to the plate and incubated for 1.5 $\mathrm{h}$ at room temperature. Fifty $\mu \mathrm{L}$ of 3-CMO-CortisolHRP (Biostride, Inc., Redwood, CA) was added and the plate was incubated for $1.5 \mathrm{~h}$ at room temperature. Substrate was added to the plate and was placed on shaker for $15 \mathrm{~min}$, after which a stop solution was applied. Plates were read at 450 and $600 \mathrm{~nm}$ on a light wave plate reader.

\section{Preweaned Calves (PWC)}

Forty Holstein heifer calves, 1 to 6 wk of age, were observed for $10 \mathrm{~d}$ after treatment. Thirty animals, 1 to $6 \mathrm{wk}$ of age, were housed indoors in individual crates, whereas the additional 10 animals, 3 to $6 \mathrm{wk}$ of age, were housed outdoors in individual hutches. Animals were fed a milk replacer with supplemental grain twice daily, according to standard herd management practices. Animals were randomly assigned to a treatment using a computer-generated table of random numbers. Treatments were: 1 ) control (C), animals were handled; 2) rubber ring dock (D), tails were cleaned and an elastrator band was applied 5 to $7 \mathrm{~cm}$ below the vulva. PWC were grouped by age after animals were randomly assigned to a treatment. PWC that were $\leq 21 \mathrm{~d}$ of age (young preweaned calves, YPWC; $\mathrm{n}=22$ ) and $>21 \mathrm{~d}$ of age (older preweaned calves, OPWC; $\mathrm{n}=18$ ) were compared.

Two previously trained individuals made behavioral observations on animals. All behaviors were recorded on a standardized form that indicated if animals were exhibiting the defined behaviors. On the day of treatment, scan observations were recorded on individual animals four times before treatment $(-60,-45,-30,-15$, and $-1 \mathrm{~min}$ ) and every $15 \mathrm{~min}$ for $5 \mathrm{~h}$ after treatment. Animals were observed once daily for $15 \mathrm{~min}$ at 0900 $\mathrm{h}$ for $9 \mathrm{~d}$ after application of treatments.

\section{Statistical Analysis}

$\boldsymbol{P P H}$. Behavioral observations were grouped into appropriate time intervals and recorded as the number of times a given behavior occurred in a given time period and were analyzed by PROC MIXED (SAS, 1999). Behavioral observations that were observed less than five times total over all observation periods for all animals were not included in the analysis. Data were analyzed in a repeated-measures model that included effects of subject (animal nested by treatment), treatment (docked, control, docked epidural, control epidural), pe$\operatorname{riod}(\mathrm{n}=7)$, and first-order interactions. Hematological measures were analyzed by comparing the difference between pretreatment values and values for $\mathrm{d} 7,14$, and 21 using PROC GLM (SAS, 1999). Data were analyzed in a repeated-measures model that included effects of subject (animal nested by treatment), treatment (docked, control, docked epidural, control epidural), pe$\operatorname{riod}(\mathrm{n}=4)$, and first-order interactions. Cortisol concentration was analyzed using PROC GLM. (SAS, 1999). Data were analyzed in a repeated-measures model that included effects of subject (animal nested by treatment), treatment (D, C, DE, CE), period ( $\mathrm{n}=12)$, and firstorder interactions. Pretreatment values ( -60 to $-1 \mathrm{~min}$ ) were compared to subsequent periods ( 1 to $60 \mathrm{~min}, 61$ to $240 \mathrm{~min}, 241$ to $720 \mathrm{~min}$, wk 1 and 2 , wk 3 and 4 , and wk 5 and 6 ).

Preweaned calves. Behavior of OPWC housed indoors in crates was compared to the behavior of OPWC housed in outdoor crates to determine if housing precluded the pooling of data. Behavioral observations were grouped into appropriate time intervals and recorded as the number of times they occurred in a given period and were analyzed by PROC MIXED (SAS, 1999). Data were analyzed in a repeated-measures model that included effects of subject (animal nested by treatment), treatment (docked, control, docked epidural, control epidural), period $(n=7)$ and first-order interactions. Pretreatment values ( -60 to $-1 \mathrm{~min}$ ) were compared to subsequent periods ( 1 to $60 \mathrm{~min}, 61$ to 120 $\mathrm{min}, 121$ to $180 \mathrm{~min}, 181$ to $240 \mathrm{~min}, 241$ to $300 \mathrm{~min}$, and $\mathrm{d} 2$ through 10 ).

\section{RESULTS}

\section{PPH}

All banded tails demonstrated progressive atrophy after application of the rubber ring (Figure 1). Tails of five animals detached without assistance between 25 and $42 \mathrm{~d}$ post treatment. Atrophied tails of the remaining seven animals were removed on $\mathrm{d} 42$.

Behavioral observations ( $\mathrm{n}=2880$ ) were recorded during the 6 -wk period of observation. Some behaviors occurred very infrequently (Table 2 ). There were no significant differences detected among treatments for any behaviors during any time period $(P>0.142)$. Within a treatment group, there were no significant differences among observation periods in the proportion of time animals were observed eating, ruminating, standing, or walking. Animals in all treatment groups maintained normal posture in both lying and standing positions for the entire length of the study.

Very little vocalization occurred in any of the animals. One animal in the CE group vocalized during the treatment day, but vocalization was not observed for the remainder of the period. There was very little tail shaking and tail tucking observed in any of the animals. 


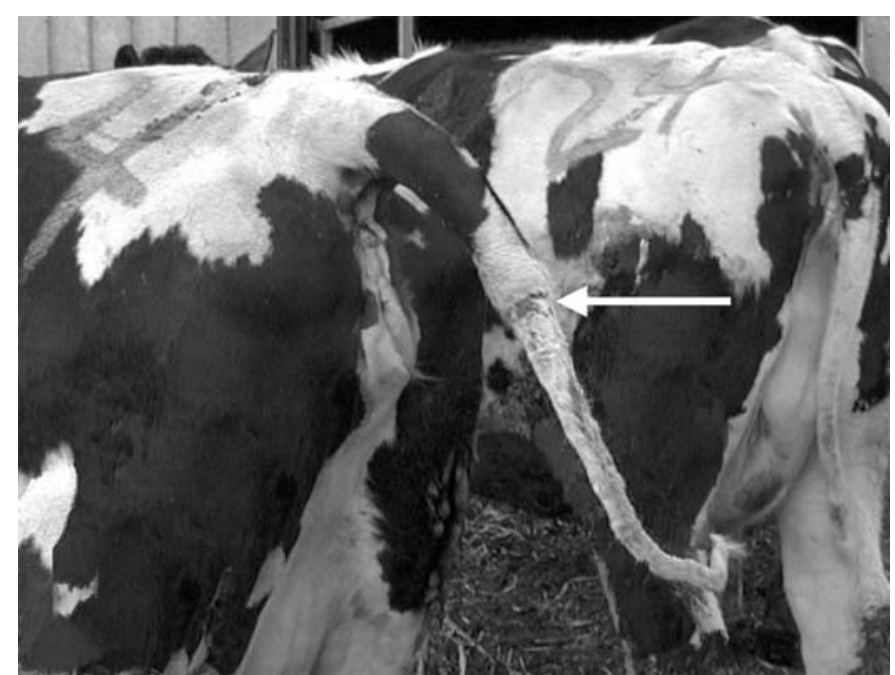

Figure 1. Preparturient heifer with atrophied tail $24 \mathrm{~d}$ after banding. Animal 4 was in the docked group. Animal 24 was in control group. Arrow indicates banding location.
Very little behavior that could be characterized as restlessness was observed. During the first hour post-treatment, some restlessness was observed in the D group, but it was not statistically significant $(P=0.39)$. Foot stamping or teeth grinding were never observed in any animals at any time.

Behavioral observations for the first $4 \mathrm{~h}$ of the study were influenced by the design of the experiment because most animals were restrained during this period. As expected, all animals stood $(P<0.001)$ during the pretreatment observation periods until 60 min after application of the tail bands because they were restrained in headlocks (Table 2). Likewise, animals walked $(P=$ 0.003) significantly less during these periods. There was no significant period effect for any other observed behaviors.

Cortisol values before treatment ranged from $0.8 \mathrm{ng} /$ $\mathrm{ml}$ to $44.6 \mathrm{ng} / \mathrm{ml}$ with a mean of $8 \mathrm{ng} / \mathrm{ml}(1.87 \mathrm{ng} / \mathrm{ml})$. The animals exhibiting the highest and lowest plasma cortisol concentrations were both control animals. Plasma cortisol concentrations were not significantly

Table 2. Percent of observations exhibiting selected behaviors of preparturient heifers by treatment and period (SE). ${ }^{1}$

\begin{tabular}{|c|c|c|c|c|c|c|c|c|}
\hline & Group $^{2}$ & \multicolumn{7}{|c|}{ Time from treatment } \\
\hline Tail shaking & $\begin{array}{l}\mathrm{C} \\
\mathrm{CE} \\
\mathrm{D} \\
\mathrm{DE}\end{array}$ & $\begin{array}{c}3.0(3.0)^{\mathrm{ab}} \\
13.0(8.3)^{\mathrm{c}} \\
0^{\mathrm{a}} \\
2.0(1.9)^{\mathrm{b}}\end{array}$ & $\begin{array}{l}4.0(2.0)^{\mathrm{b}} \\
3.3(2.0)^{\mathrm{b}} \\
5.3(2.2)^{\mathrm{b}} \\
1.3(1.3)^{\mathrm{ab}}\end{array}$ & $\begin{array}{l}2.0(2.0)^{\mathrm{b}} \\
0^{\mathrm{a}} \\
1.7(1.7)^{\mathrm{a}} \\
0^{\mathrm{a}}\end{array}$ & $\begin{array}{l}0^{\mathrm{a} 1} \\
0^{\mathrm{a}} \\
0^{\mathrm{a}} \\
0^{\mathrm{a}}\end{array}$ & $\begin{array}{l}1.4(1.0)^{\mathrm{b}} \\
0^{\mathrm{a}} \\
0^{\mathrm{a}} \\
0^{\mathrm{a}}\end{array}$ & $\begin{array}{ll}1.1 & (1.1)^{\mathrm{a}} \\
1.5 & (1.5)^{\mathrm{ab}} \\
0.7 & (0.6)^{\mathrm{a}} \\
0^{\mathrm{a}} & \end{array}$ & $\begin{array}{l}0^{\mathrm{a}} \\
0^{\mathrm{a}} \\
0^{\mathrm{a}} \\
0^{\mathrm{a}}\end{array}$ \\
\hline Standing & $\begin{array}{l}\mathrm{C} \\
\mathrm{CE} \\
\mathrm{D} \\
\mathrm{DE}\end{array}$ & $\begin{array}{l}100.0(0.0)^{\mathrm{e}} \\
100.0(0.0)^{\mathrm{e}} \\
100.0(0.0)^{\mathrm{e}} \\
100.0(0.0)^{\mathrm{d}}\end{array}$ & $\begin{array}{l}100.0(0.0)^{\mathrm{e}} \\
100.0(0.0)^{\mathrm{e}} \\
100.0(0.0)^{\mathrm{e}} \\
100.0(0.0)^{\mathrm{d}}\end{array}$ & $\begin{array}{l}95.0(3.0)^{\mathrm{d}} \\
88.3(5.0)^{\mathrm{d}} \\
91.7(3.7)^{\mathrm{d}} \\
90.5(5.3)^{\mathrm{c}}\end{array}$ & $\begin{array}{l}56.0(5.0)^{\mathrm{a}} \\
42.5(5.0)^{\mathrm{a}} \\
43.8(4.4)^{\mathrm{a}} \\
41.1(4.7)^{\mathrm{a}}\end{array}$ & $\begin{array}{l}63.0(2.0)^{\mathrm{ab}} \\
57.6(2.7)^{\mathrm{b}} \\
59.7(1.9)^{\mathrm{b}} \\
63.6(3.5)^{\mathrm{b}}\end{array}$ & $\begin{array}{l}70.6(3.3)^{\mathrm{c}} \\
63.8(4.6)^{\mathrm{bc}} \\
71.1(4.9)^{\mathrm{c}} \\
65.4(2.2)^{\mathrm{b}}\end{array}$ & $\begin{array}{l}69.0(4.7)^{\mathrm{bc}} \\
72.9(5.5)^{\mathrm{c}} \\
62.1(12.0)^{\mathrm{bc}} \\
56.4(10.7)^{\mathrm{b}}\end{array}$ \\
\hline Eating & $\begin{array}{l}\mathrm{C} \\
\mathrm{CE} \\
\mathrm{D} \\
\mathrm{DE}\end{array}$ & $\begin{array}{c}20.0(12.0) \\
24.0(11.7) \\
36.0 \\
8.6\end{array}$ & $\begin{array}{ll}10.0 & (5.0) \\
18.3 & (10.3) \\
29.3 & (11.2) \\
16.9 & (6.3)\end{array}$ & $\begin{array}{l}22.0(6.0) \\
18.3(6.1) \\
20.0(6.2) \\
19.8(4.9)\end{array}$ & $\begin{array}{l}23.0(4.0) \\
19.7(4.4) \\
17.5(3.6) \\
16.1(2.3)\end{array}$ & $\begin{array}{ll}25.0 & (2.0) \\
24.6(5.3) \\
19.8(2.8) \\
26.4(2.7)\end{array}$ & $\begin{array}{ll}30.0 & (4.8) \\
25.8 & (4.7) \\
20.8 & (4.0) \\
28.6 & (3.4)\end{array}$ & $\begin{array}{ll}28.5 & (3.1) \\
35.2 & (9.5) \\
21.2 & (6.1) \\
20.6 & (5.1)\end{array}$ \\
\hline Ruminating & $\begin{array}{l}\mathrm{C} \\
\mathrm{CE} \\
\mathrm{D} \\
\mathrm{DE}\end{array}$ & $\begin{array}{l}30.0(5.0) \\
24.0(7.5) \\
32.0(8.0)^{\mathrm{bc}} \\
20.0(4.4)^{\mathrm{ab}}\end{array}$ & $\begin{array}{l}17.0(3.7) \\
20.0(5.0) \\
17.0(3.7)^{\mathrm{a}} \\
23.6(5.8)^{\mathrm{ab}}\end{array}$ & $\begin{array}{l}23.0(5.0) \\
25.0(4.6) \\
15.0(3.1)^{\mathrm{a}} \\
15.0(3.9)^{\mathrm{a}}\end{array}$ & $\begin{array}{l}23.0(5.0) \\
31.3(5.1) \\
28.8(8.8)^{\mathrm{b}} \\
34.8(3.0)^{\mathrm{a}}\end{array}$ & $\begin{array}{l}22.0(2.0) \\
24.4(3.7) \\
26.9(2.8)^{\mathrm{b}} \\
26.2(3.7)^{\mathrm{b}}\end{array}$ & $\begin{array}{l}19.4(3.6) \\
36.2(8.4) \\
27.7(2.8)^{\mathrm{b}} \\
24.7(1.1)^{\mathrm{b}}\end{array}$ & $\begin{array}{l}19.0(3.0) \\
27.4(5.5) \\
41.3(6.5)^{\mathrm{c}} \\
24.0(5.2)^{\mathrm{b}}\end{array}$ \\
\hline Vocalization & $\begin{array}{l}\mathrm{C} \\
\mathrm{CE} \\
\mathrm{D} \\
\mathrm{DE}\end{array}$ & $\begin{array}{l}0^{\mathrm{a}} \\
4.0(4.0) \\
0 \\
0\end{array}$ & $\begin{array}{l}0^{\mathrm{a}} \\
0 \\
0 \\
0\end{array}$ & $\begin{array}{l}0^{\mathrm{a}} \\
1.7 \quad(1.7) \\
0 \\
0\end{array}$ & $\begin{array}{l}0^{\mathrm{a}} \\
0 \\
0 \\
0\end{array}$ & $\begin{array}{l}1.0(0.5)^{\mathrm{b}} \\
0 \\
0 \\
0\end{array}$ & $\begin{array}{l}0^{\mathrm{a}} \\
0 \\
0 \\
0\end{array}$ & $\begin{array}{l}0^{\mathrm{a}} \\
0 \\
0 \\
0\end{array}$ \\
\hline Walking & $\begin{array}{l}\mathrm{C} \\
\mathrm{CE} \\
\mathrm{D} \\
\mathrm{DE}\end{array}$ & $\begin{array}{l}3.0(3.0)^{\mathrm{ab}} \\
0^{\mathrm{a}} \\
0^{\mathrm{a}} \\
0^{\mathrm{a}}\end{array}$ & $\begin{array}{l}0^{\mathrm{a}} \\
0^{\mathrm{a}} \\
0^{\mathrm{a}} \\
0^{\mathrm{a}}\end{array}$ & $\begin{array}{l}1.0(1.0)^{\mathrm{ab}} \\
3.3(3.3)^{\mathrm{ab}} \\
0^{\mathrm{a}} \\
1.2(1.2)^{\mathrm{ab}}\end{array}$ & $\begin{array}{l}3.0(2.0)^{b} \\
2.5(1.5)^{b} \\
5.0(3.1)^{b} \\
2.7(1.3)^{b}\end{array}$ & $\begin{array}{l}4.6(1.0)^{b} \\
3.4(1.2)^{b} \\
4.7(1.6)^{b} \\
3.0(1.1)^{b}\end{array}$ & $\begin{array}{l}4.5(2.5)^{\mathrm{b}} \\
1.5(0.9)^{\mathrm{b}} \\
6.3(3.0)^{\mathrm{b}} \\
4.9(3.8)^{\mathrm{bc}}\end{array}$ & $\begin{array}{l}2.3(1.5)^{\mathrm{b}} \\
1.7(1.7)^{\mathrm{ab}} \\
3.9(2.4)^{\mathrm{b}} \\
7.4(2.9)^{\mathrm{c}}\end{array}$ \\
\hline
\end{tabular}

a,b,c,d,e Means in the same row with different superscripts vary $(P<0.05)$.

${ }^{1} 0=$ behavior not observed.

${ }^{2} \mathrm{C}=$ control, $\mathrm{CE}=$ control with epidural, $\mathrm{D}=$ docked, $\mathrm{DE}=$ docking with epidural. 


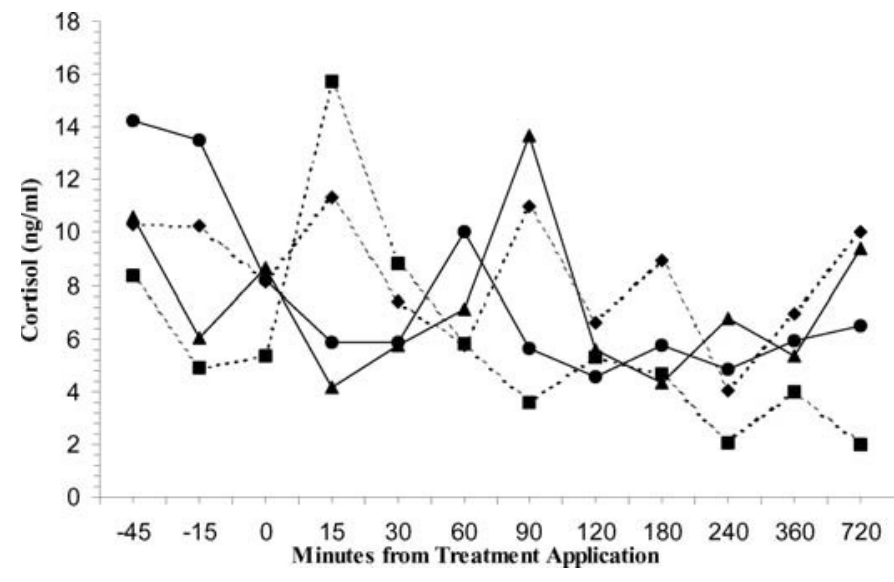

Figure 2. Circulating cortisol concentration $(\mathrm{ng} / \mathrm{ml})$ by treatment and period for preparturient heifers $(\mathrm{SEM}=1.87)$. Legend: control

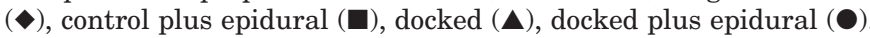
No significant differences were detected $(P=0.16)$.

affected by treatment $(P=0.49$; Figure 2$)$. There was no significant difference in plasma cortisol concentration within groups over the observation period $(P=0.16)$. There was no significant treatment $\times$ time interaction during the observation period $(P=0.36)$.

All hematological data, except for neutrophils, were within normal limits (as defined by the reference laboratory) for the entire study period (Table 3 ). With the exception of eosinophils, no significant differences were detected among treatments in mean hematological values for the entire study period $(P>0.29)$. The proportion of eosinophils was significantly higher for animals receiving epidurals (DE and $\mathrm{CE}$ ) compared to animals in the D group $(P<0.01)$.

There were no significant changes in hematological data among groups that could be related to treatment $(P>0.17)$. There were no significant treatment $\times$ day interactions for any hematological data $(P>0.42)$. Neutrophils slightly exceeded the reference range supplied by the laboratory on $\mathrm{d} 7,14$, and 21 for all groups (Table $3)$. Red blood count $(P=0.012)$ and hemoglobin $(P=$ 0.022 ) values increased with time for all treatments (Table 3). Some treatment groups experienced minor changes in hematological values with time, but there were no significant changes in WBC, hematocrit, monocyte, neutrophil, or lymphocyte levels across time that could be attributed to treatment (Table 3 ).

There was no significant difference $(P=0.99)$ in heart rate among treatment groups throughout the study (Figure 3). Body temperatures were within limits previously described for healthy cattle in temperate environments for the entire study period (Rebhun, 1995). There was no significant difference observed in body temperature between treatment groups $(P=0.42)$ dur- ing the entire study period. Body temperature was found to be significantly higher $(P<0.001)$ for all animals on 1 compared to the remainder of the study (Figure 4).

\section{PWC}

No tails of PWC detached during the 10-d observation period. There was no significant difference in behavior between OPWC calves housed indoors or outdoors $(P$ $>0.151$ ); therefore, the data were pooled for further analysis. Many behaviors were not observed during any period (Table 4). All calves exhibited normal posture for the entire observation period, and no animals displayed tail tucking during the observation period. No significant differences in eating, standing, or walking $(P>$ $0.25)$ were detected among treatments. Docked OPWC tended to spend more time in rear visualization compared to OPWC in the control group $(P=0.056)$. Significantly more restlessness was observed in the docked OPWC compared to control OPWC $(P=0.01)$ after application of bands on the day of treatment and on $\mathrm{d} 8$ and 9 (Figure 5). OPWC for both treatments spent significantly more time in behaviors characterized as tail shaking, playing, vocalizing, stamping feet, and restless compared to YPWC $(P<0.004)$. Significant period differences were observed for all groups for eating, rear visualization, standing, tail shaking, playing, vocalization, and foot stomping (Table 4).

\section{DISCUSSION}

Pain has been defined as an adverse sensory and emotional experience representing awareness by the animal of damage or threat to the integrity of its tissues; thus changing the animal's physiology and behavior to reduce or avoid damage and to promote recovery (Molony and Kent, 1997). Our ability to detect subtle levels of discomfort and pain in animals is based upon monitoring behavioral and physiological data while attempting to minimize potential effects of the data collection process. In our study, we collected both physiological data and behavioral observations. The behavioral data collected for PWC was collected without any interaction between the observer and the animals and should have been only influenced by the randomly assigned treatment. Data collection for PPH required restraint and handling of animals for some of the data collection periods. Obviously, behavior of the PPH was affected during periods when the animals were restrained; however, all animals included in the study were handled in a similar manner, without regard to assigned treatment, and the influence of restraint and handling should have been equally distributed among 

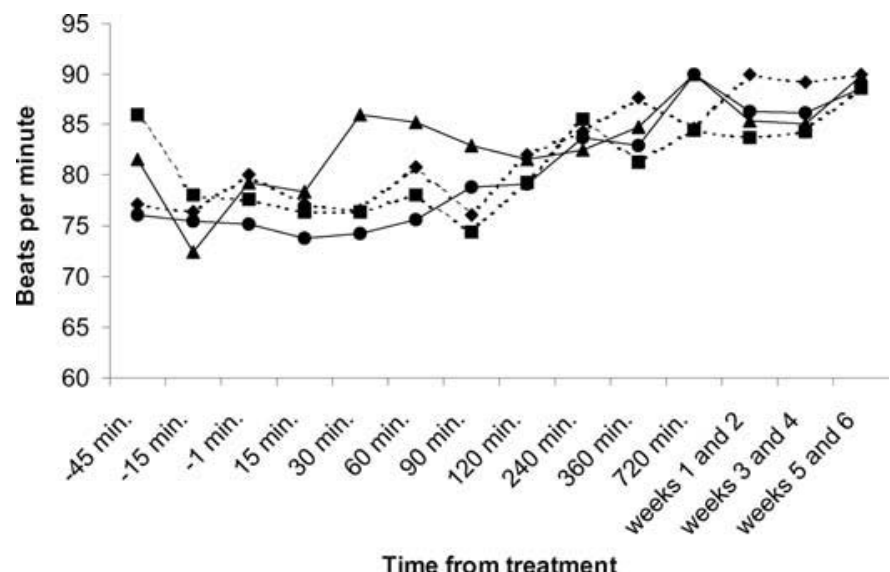

Figure 3. Heart rate by treatment and period for preparturient heifers $(\mathrm{SEM}=0.29)$. Legend: control $(\bullet)$, control plus epidural $(\mathbf{\square})$, docked ( $\mathbf{\Lambda})$, docked plus epidural $(\bullet)$. No significant differences between treatments were detected $(P=0.99)$.

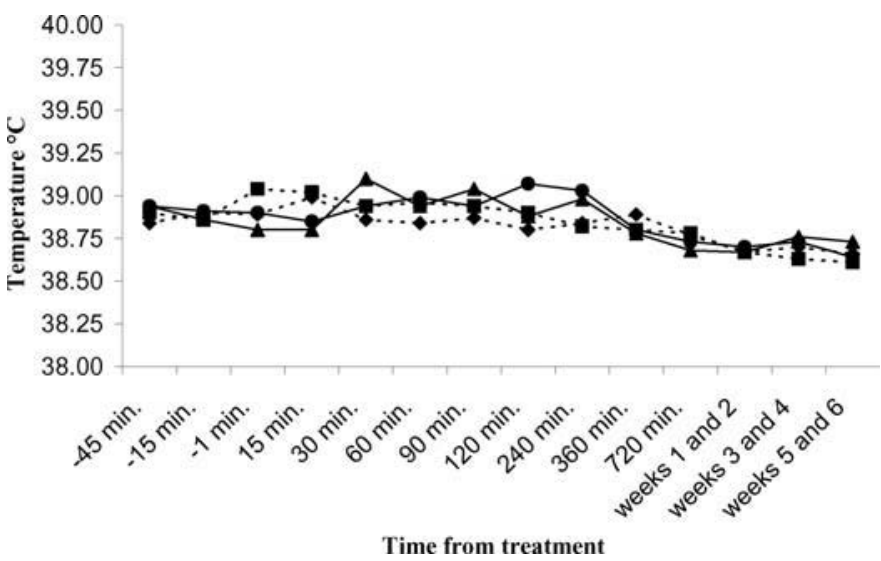

Figure 4. Body temperature $\left({ }^{\circ} \mathrm{C}\right)$ by treatment and period for preparturient heifers (SEM $=0.12$ ). Legend: control $(\diamond)$, control plus epidural ( $\square$ ), docked $(\mathbf{\Delta})$, docked plus epidural $(\mathbf{\bullet})$. No significant differences between treatments were detected $(P=0.42)$.

Table 3. Hematological values and changes from pretreatment by treatment on d 7, 14, and 21 (SE) for preparturient heifers. ${ }^{1}$

\begin{tabular}{|c|c|c|c|c|c|c|c|c|c|c|}
\hline \multirow[b]{2}{*}{ Component } & \multirow[b]{2}{*}{ Group } & \multirow[b]{2}{*}{ Reference $^{2}$} & \multicolumn{8}{|c|}{ Mean change from baseline (SE) } \\
\hline & & & Pretreatment & $\mathrm{SE}$ & d 7 & $\mathrm{SE}$ & d 14 & $\mathrm{SE}$ & d 21 & $\mathrm{SE}$ \\
\hline $\mathrm{RBC}, \times 10^{6} / \mu \mathrm{l}$ & $\begin{array}{l}\mathrm{C} \\
\mathrm{CE} \\
\mathrm{D} \\
\mathrm{DE}\end{array}$ & $5-10$ & $\begin{array}{l}6.89^{\mathrm{a}} \\
6.74^{\mathrm{a}} \\
6.92 \\
6.90\end{array}$ & $\begin{array}{l}0.20 \\
0.23 \\
0.42 \\
0.17\end{array}$ & $\begin{array}{l}0.21^{\mathrm{ab}} \\
0.15^{\mathrm{ab}} \\
0.12 \\
0.16\end{array}$ & $\begin{array}{l}0.18 \\
0.19 \\
0.19 \\
0.25\end{array}$ & $\begin{array}{l}0.36^{\mathrm{ab}} \\
0.10^{\mathrm{a}} \\
0.18 \\
0.24\end{array}$ & $\begin{array}{l}0.12 \\
0.20 \\
0.21 \\
0.27\end{array}$ & $\begin{array}{l}0.54^{\mathrm{b}} \\
0.55^{\mathrm{b}} \\
0.29 \\
0.30\end{array}$ & $\begin{array}{l}0.18 \\
0.22 \\
0.35 \\
0.20\end{array}$ \\
\hline Hematocrit, \% & $\begin{array}{l}\mathrm{C} \\
\mathrm{CE} \\
\mathrm{D} \\
\mathrm{DE}\end{array}$ & $24-46$ & $\begin{array}{l}33.33^{\mathrm{a}} \\
33.48 \\
33.86 \\
33.71\end{array}$ & $\begin{array}{l}0.75 \\
0.98 \\
1.90 \\
0.76\end{array}$ & $\begin{array}{l}2.91^{\mathrm{b}} \\
0.90 \\
0.38 \\
0.84\end{array}$ & $\begin{array}{l}1.93 \\
0.97 \\
0.99 \\
1.15\end{array}$ & $\begin{array}{l}1.70^{\mathrm{a}} \\
0.82 \\
0.94 \\
1.54\end{array}$ & $\begin{array}{l}0.75 \\
1.02 \\
1.15 \\
1.32\end{array}$ & $\begin{array}{l}1.66^{\mathrm{a}} \\
3.02 \\
1.80 \\
1.53\end{array}$ & $\begin{array}{l}1.05 \\
1.30 \\
2.10 \\
0.85\end{array}$ \\
\hline Hemoglobin, g/dl & $\begin{array}{l}\mathrm{C} \\
\mathrm{CE} \\
\mathrm{D} \\
\mathrm{DE}\end{array}$ & $8-15$ & $\begin{array}{c}11.57 \\
11.72 \\
9.86^{\mathrm{a}} \\
11.76\end{array}$ & $\begin{array}{l}0.26 \\
0.35 \\
2.14 \\
0.27\end{array}$ & $\begin{array}{l}0.44 \\
0.34 \\
2.22^{\mathrm{b}} \\
0.41\end{array}$ & $\begin{array}{l}0.32 \\
0.39 \\
2.12 \\
0.39\end{array}$ & $\begin{array}{l}0.53 \\
0.26 \\
2.40^{\mathrm{b}} \\
0.57\end{array}$ & $\begin{array}{l}0.23 \\
0.33 \\
2.05 \\
0.41\end{array}$ & $\begin{array}{c}0.01 \\
0.54 \\
2.02^{\mathrm{b}} \\
(0.20)\end{array}$ & $\begin{array}{l}0.19 \\
0.36 \\
1.94 \\
0.24\end{array}$ \\
\hline $\mathrm{WBC}, \times 10^{3} / \mu \mathrm{l}$ & $\begin{array}{l}\mathrm{C} \\
\mathrm{CE} \\
\mathrm{D} \\
\mathrm{DE}\end{array}$ & $4-12$ & $\begin{array}{r}7.03 \\
7.08 \\
6.54 \\
12.97\end{array}$ & $\begin{array}{l}0.53 \\
0.54 \\
1.69 \\
6.08\end{array}$ & $\begin{array}{l}0.13 \\
0.76 \\
2.64 \\
0.46\end{array}$ & $\begin{array}{l}0.66 \\
0.40 \\
1.76 \\
8.15\end{array}$ & $\begin{array}{c}0.33 \\
0.74 \\
2.30 \\
(5.27)\end{array}$ & $\begin{array}{l}0.76 \\
0.40 \\
1.85 \\
5.90\end{array}$ & $\begin{array}{c}2.49 \\
3.08 \\
3.92 \\
(3.54)\end{array}$ & $\begin{array}{l}1.31 \\
0.45 \\
1.99 \\
6.00\end{array}$ \\
\hline Neutrophil, \% & $\begin{array}{l}\mathrm{C} \\
\mathrm{CE} \\
\mathrm{D} \\
\mathrm{DE}\end{array}$ & $15-45$ & $\begin{array}{l}37.14^{\mathrm{a}} \\
41.40 \\
48.40 \\
46.86\end{array}$ & $\begin{array}{l}5.48 \\
7.52 \\
9.01 \\
5.42\end{array}$ & $\begin{array}{c}10.57^{\mathrm{ab}} \\
11.60 \\
1.60 \\
(1.71)\end{array}$ & $\begin{array}{r}6.91 \\
11.30 \\
4.60 \\
6.53\end{array}$ & $\begin{array}{l}8.57^{\mathrm{ab}} \\
8.80 \\
8.00 \\
(3.43)\end{array}$ & $\begin{array}{r}8.44 \\
10.58 \\
12.80 \\
6.50\end{array}$ & $\begin{array}{c}22.57^{\mathrm{b}} \\
8.40 \\
3.20 \\
(4.43)\end{array}$ & $\begin{array}{l}7.03 \\
9.85 \\
7.63 \\
6.05\end{array}$ \\
\hline Eosinophil, \% & $\begin{array}{l}\mathrm{C} \\
\mathrm{CE} \\
\mathrm{D} \\
\mathrm{DE}\end{array}$ & $2-20$ & $\begin{array}{l}5.57 \\
8.40 \\
2.80 \\
5.71^{\mathrm{ab}}\end{array}$ & $\begin{array}{l}1.84 \\
2.98 \\
0.80 \\
1.13\end{array}$ & $\begin{array}{l}1.86 \\
2.40 \\
1.00 \\
2.29^{\mathrm{ab}}\end{array}$ & $\begin{array}{l}1.55 \\
4.33 \\
1.27 \\
1.91\end{array}$ & $\begin{array}{l}1.14 \\
1.60 \\
0.00 \\
4.43^{\mathrm{b}}\end{array}$ & $\begin{array}{l}2.46 \\
3.52 \\
1.05 \\
3.55\end{array}$ & $\begin{array}{l}0.00 \\
0.40 \\
0.60 \\
0.43^{\mathrm{a}}\end{array}$ & $\begin{array}{l}1.83 \\
3.12 \\
2.06 \\
1.40\end{array}$ \\
\hline Monocyte, \% & $\begin{array}{l}\mathrm{C} \\
\mathrm{CE} \\
\mathrm{D} \\
\mathrm{DE}\end{array}$ & $2-7$ & $\begin{array}{l}3.43 \\
4.60 \\
4.20 \\
3.86\end{array}$ & $\begin{array}{l}0.72 \\
0.93 \\
0.58 \\
1.53\end{array}$ & $\begin{array}{c}0.14 \\
(0.20) \\
1.80 \\
0.71\end{array}$ & $\begin{array}{l}1.24 \\
2.04 \\
0.86 \\
1.41\end{array}$ & $\begin{array}{l}2.14 \\
2.00 \\
1.80 \\
1.00\end{array}$ & $\begin{array}{l}1.77 \\
3.19 \\
1.80 \\
1.68\end{array}$ & $\begin{array}{c}0.57 \\
1.00 \\
(0.40) \\
0.43\end{array}$ & $\begin{array}{l}1.53 \\
1.52 \\
0.25 \\
2.02\end{array}$ \\
\hline
\end{tabular}

${ }^{\mathrm{a}, \mathrm{b}}$ Values with different letters within rows changed significantly from pretreatment values $(P<0.05)$.

${ }^{1} \mathrm{C}=$ control, $\mathrm{CE}=$ control with epidural, $\mathrm{D}=$ docked, $\mathrm{DE}=$ docking with epidural.

${ }^{2}$ Marshfield Laboratories Veterinary Diagnostic Services, Marshfield, WI. 
Table 4. Percent of observations exhibiting selected behaviors by treatment and period for preweaned calves (SE). ${ }^{1}$

\begin{tabular}{|c|c|c|c|c|c|c|c|c|}
\hline & \multirow[b]{2}{*}{ Group } & \multicolumn{7}{|c|}{ Time from treatment ${ }^{2}$} \\
\hline & & Pretreatment & $1-60 \mathrm{~min}$ & $61-120 \mathrm{~min}$ & $121-180 \mathrm{~min}$ & $181-240 \mathrm{~min}$ & $241-300 \mathrm{~min}$ & $2-10 \mathrm{~d}$ \\
\hline Eating & $\begin{array}{l}\text { YD } \\
\text { OD } \\
\text { YC } \\
\text { OC }\end{array}$ & $\begin{array}{l}18.2(3.0)^{\mathrm{b}} \\
22.2(4.0)^{\mathrm{c}} \\
23.6(2.4)^{\mathrm{b}} \\
17.8(5.2)^{\mathrm{b}}\end{array}$ & $\begin{array}{c}0^{\mathrm{a} 1} \\
11.1(4.4)^{\mathrm{b}} \\
0^{\mathrm{a}} \\
11.1(6.1)^{\mathrm{b}}\end{array}$ & $\begin{array}{l}2.3(2.3)^{\mathrm{a}} \\
8.3(5.9)^{\mathrm{b}} \\
0^{\mathrm{a}} \\
0^{\mathrm{a}}\end{array}$ & $\begin{array}{l}0^{\mathrm{a}} \\
0^{\mathrm{a}} \\
2.2(0.0)^{\mathrm{a}} \\
2.8(2.8)^{\mathrm{a}}\end{array}$ & $\begin{array}{l}0^{\mathrm{a}} \\
0^{\mathrm{a}} \\
0^{\mathrm{a}} \\
0^{\mathrm{a}}\end{array}$ & $\begin{array}{l}2.3(2.3)^{\mathrm{a}} \\
0^{\mathrm{a}} \\
2.3(2.3)^{\mathrm{a}} \\
0^{\mathrm{a}}\end{array}$ & $\begin{array}{l}3.0(2.2)^{\mathrm{a}} \\
2.5(1.6)^{\mathrm{ab}} \\
1.0(1.0)^{\mathrm{a}} \\
0^{\mathrm{a}}\end{array}$ \\
\hline Rear visualization & $\begin{array}{l}\text { YD } \\
\text { OD } \\
\text { YC } \\
\text { OC }\end{array}$ & $\begin{array}{l}1.8(1.8)^{\mathrm{ab}} \\
0^{\mathrm{a}} \\
1.8(1.8) \\
0\end{array}$ & $\begin{array}{l}2.3(2.3)^{\mathrm{ab}} \\
8.3(5.9)^{\mathrm{b}} \\
0 \\
2.8(2.8)\end{array}$ & $\begin{array}{l}4.5(3.0)^{\mathrm{b}} \\
5.6(5.6)^{\mathrm{ab}} \\
0 \\
0\end{array}$ & $\begin{array}{l}0^{\mathrm{a}} \\
2.8(2.8)^{\mathrm{ab}} \\
0 \\
0\end{array}$ & $\begin{array}{l}0^{\mathrm{a}} \\
0 \\
0 \\
0\end{array}$ & $\begin{array}{l}0^{\mathrm{a}} \\
0 \\
0 \\
0\end{array}$ & $\begin{array}{l}0^{\mathrm{a}} \\
1.2(1.2)^{\mathrm{a}} \\
0 \\
0\end{array}$ \\
\hline Standing & $\begin{array}{l}\text { YD } \\
\text { OD } \\
\text { YC } \\
\text { OC }\end{array}$ & $\begin{array}{l}83.6(6.5)^{\mathrm{e}} \\
86.7(5.8)^{\mathrm{d}} \\
87.3(3.0)^{\mathrm{d}} \\
95.6(2.9)^{\mathrm{c}}\end{array}$ & $\begin{array}{l}47.7(9.2)^{\mathrm{cd}} \\
58.4(11.0)^{\mathrm{c}} \\
25.0(8.3)^{\mathrm{bc}} \\
41.7(7.2)^{\mathrm{b}}\end{array}$ & $\begin{aligned} 9.1(3.8)^{\mathrm{a}} \\
25.0(7.2)^{\mathrm{b}} \\
6.8(6.8)^{\mathrm{a}} \\
13.9(6.1)^{\mathrm{a}}\end{aligned}$ & $\begin{array}{l}25.0(5.8)^{\mathrm{b}} \\
11.0(4.4)^{\mathrm{a}} \\
13.6(6.2)^{\mathrm{ab}} \\
19.4(11.6)^{\mathrm{a}}\end{array}$ & $\begin{array}{r}20.5(6.6)^{\mathrm{b}} \\
5.6(3.7)^{\mathrm{a}} \\
13.6(3.9)^{\mathrm{ab}} \\
13.9(6.1)^{\mathrm{a}}\end{array}$ & $\begin{array}{l}31.8(10.2)^{\mathrm{bc}} \\
25.0(9.3)^{\mathrm{b}} \\
34.1(10.3)^{\mathrm{c}} \\
19.4(11.6)^{\mathrm{a}}\end{array}$ & $\begin{array}{l}49.5(6.1)^{\mathrm{d}} \\
42.0(8.4)^{\mathrm{bc}} \\
49.5(7.1)^{\mathrm{c}} \\
39.5(7.7)^{\mathrm{b}}\end{array}$ \\
\hline Walking & $\begin{array}{l}\text { YD } \\
\text { OD } \\
\text { YC } \\
\text { OC }\end{array}$ & $\begin{array}{l}0 \\
0^{\mathrm{a}} \\
1.8(1.8) \\
2.2(2.2)\end{array}$ & $\begin{array}{l}2.3(2.3) \\
2.8(2.8)^{\mathrm{ab}} \\
0 \\
0\end{array}$ & $\begin{array}{l}0 \\
5.6(3.7)^{\mathrm{b}} \\
0 \\
2.8(2.8)\end{array}$ & $\begin{array}{l}0 \\
5.6(3.7)^{\mathrm{b}} \\
0 \\
0\end{array}$ & $\begin{array}{l}0 \\
0^{\mathrm{a}} \\
0 \\
0\end{array}$ & $\begin{array}{l}0 \\
0^{\mathrm{a}} \\
0 \\
0\end{array}$ & $\begin{array}{l}0 \\
0^{\mathrm{a}} \\
0 \\
1.2(1.2)\end{array}$ \\
\hline Tail shaking & $\begin{array}{l}\text { YD } \\
\text { OD } \\
\text { YC } \\
\text { OC }\end{array}$ & $\begin{array}{c}0 \\
15.6(8.0)^{\mathrm{c}} \\
0 \\
15.6(9.3)^{\mathrm{b}}\end{array}$ & $\begin{array}{l}0 \\
19.4(10.8)^{\mathrm{c}} \\
0 \\
2.8(2.8)^{\mathrm{ab}}\end{array}$ & $\begin{array}{l}0 \\
2.8(2.8)^{\mathrm{ab}} \\
0 \\
5.6(5.6)^{\mathrm{ab}}\end{array}$ & $\begin{array}{l}0 \\
0^{\mathrm{a}} \\
0 \\
0^{\mathrm{a}}\end{array}$ & $\begin{array}{l}0 \\
0^{\mathrm{a}} \\
0 \\
0^{\mathrm{a}}\end{array}$ & $\begin{array}{l}0 \\
2.8(2.8)^{\mathrm{ab}} \\
0 \\
0^{\mathrm{a}}\end{array}$ & $\begin{array}{l}0 \\
3.7(2.6)^{b} \\
0 \\
7.4(5.2)^{b}\end{array}$ \\
\hline Playing & $\begin{array}{l}\text { YD } \\
\text { OD } \\
\text { YC } \\
\text { OC }\end{array}$ & $\begin{array}{l}5.5(2.8)^{\mathrm{b}} \\
2.2(2.2) \\
3.6(3.6)^{\mathrm{ab}} \\
8.9(6.8)^{\mathrm{b}}\end{array}$ & $\begin{array}{l}0^{\mathrm{a}} \\
0 \\
0^{\mathrm{a}} \\
0^{\mathrm{a}}\end{array}$ & $\begin{array}{l}0^{\mathrm{a}} \\
0 \\
0^{\mathrm{a}} \\
0^{\mathrm{a}}\end{array}$ & $\begin{array}{l}0^{\mathrm{a}} \\
0 \\
0^{\mathrm{a}} \\
0^{\mathrm{a}}\end{array}$ & $\begin{array}{l}0^{\mathrm{a}} \\
0 \\
0^{\mathrm{a}} \\
0^{\mathrm{a}}\end{array}$ & $\begin{array}{l}0^{\mathrm{a}} \\
0 \\
0^{\mathrm{a}} \\
0^{\mathrm{a}}\end{array}$ & $\begin{array}{ll}2.0 & (1.4)^{\mathrm{b}} \\
1.2(1.2) \\
2.0(1.4)^{\mathrm{b}} \\
0^{\mathrm{a}}\end{array}$ \\
\hline Vocalization & $\begin{array}{l}\text { YD } \\
\text { OD } \\
\text { YC } \\
\text { OC }\end{array}$ & $\begin{array}{l}0 \\
8.9(6.9)^{\mathrm{b}} \\
0 \\
6.7(3.3)^{\mathrm{b}}\end{array}$ & $\begin{array}{l}0 \\
2.8(2.8)^{\mathrm{ab}} \\
0 \\
0^{\mathrm{a}}\end{array}$ & $\begin{array}{l}0 \\
2.8(2.8)^{\mathrm{ab}} \\
0 \\
0^{\mathrm{a}}\end{array}$ & $\begin{array}{l}0 \\
0^{\mathrm{a}} \\
0 \\
0^{\mathrm{a}}\end{array}$ & $\begin{array}{l}0 \\
0^{\mathrm{a}} \\
0 \\
0^{\mathrm{a}}\end{array}$ & $\begin{array}{l}0 \\
0^{\mathrm{a}} \\
0 \\
0^{\mathrm{a}}\end{array}$ & $\begin{array}{l}0 \\
1.2(1.2)^{\mathrm{ab}} \\
0 \\
1.2(1.2)^{\mathrm{a}}\end{array}$ \\
\hline Foot stomping & $\begin{array}{l}\text { YD } \\
\text { OD } \\
\text { YC } \\
\text { OC }\end{array}$ & $\begin{array}{l}7.3(3.0)^{\mathrm{b}} \\
2.2(2.2)^{\mathrm{ab}} \\
3.6(2.4)^{\mathrm{b}} \\
2.2(2.2)\end{array}$ & $\begin{array}{l}2.3(2.3)^{\mathrm{ab}} \\
0^{\mathrm{a}} \\
0^{\mathrm{a}} \\
0\end{array}$ & $\begin{array}{l}0^{\mathrm{a}} \\
8.3(4.2)^{\mathrm{b}} \\
0^{\mathrm{a}} \\
0\end{array}$ & $\begin{array}{l}2.3(2.3)^{\mathrm{ab}} \\
0^{\mathrm{a}} \\
0^{\mathrm{a}} \\
0\end{array}$ & $\begin{array}{l}2.3(2.3)^{\mathrm{ab}} \\
0^{\mathrm{a}} \\
0^{\mathrm{a}} \\
0\end{array}$ & $\begin{array}{l}0^{\mathrm{a}} \\
0^{\mathrm{a}} \\
0^{\mathrm{a}} \\
0\end{array}$ & $\begin{array}{l}0^{\mathrm{a}} \\
0^{\mathrm{a}} \\
0^{\mathrm{a}} \\
1.2(1.2)\end{array}$ \\
\hline Standing stiff & $\begin{array}{l}\text { YD } \\
\text { OD } \\
\text { YC } \\
\text { OC }\end{array}$ & $\begin{array}{l}0 \\
0 \\
0 \\
0\end{array}$ & $\begin{array}{l}0 \\
2.8 \quad(2.8) \\
0 \\
0\end{array}$ & $\begin{array}{l}0 \\
0 \\
0 \\
0\end{array}$ & $\begin{array}{l}0 \\
0 \\
0 \\
5.6(5.6)\end{array}$ & $\begin{array}{l}0 \\
0 \\
0 \\
0\end{array}$ & $\begin{array}{l}0 \\
0 \\
0 \\
0\end{array}$ & $\begin{array}{l}1.0(1.0) \\
0 \\
0 \\
0\end{array}$ \\
\hline
\end{tabular}

a,b,c,d,e Means within a row with different superscripts vary $(P<0.05)$.

${ }^{1} \mathrm{Y}=$ young, $\mathrm{O}=$ old, $\mathrm{C}=$ control, $\mathrm{D}=$ docked.

${ }^{2} 0=$ behavior not observed.

groups. Likewise, dairy animals are routinely handled throughout their lifetimes, and we were not attempting to describe behavioral patterns of dairy cows, but we were attempting to determine if the process of tail docking and tail atrophy had a measurable and observable effect on them.

Eicher et al. (2000) examined short-term behavioral, immunological, and endocrine responses to tail banding with and without local anesthesia. Twenty-one primiparous heifers were observed for $24 \mathrm{~h}$ before and after application of tail bands, and $4 \mathrm{~d}$ later, the animals were monitored for $24 \mathrm{~h}$ before and after removal of the atrophied tails. The authors concluded that tail banding did not significantly affect cortisol or immune measures, but docked heifers were observed to spend more time eating after application of the bands and less time eating after removal of the tail compared to control heifers (Eicher et al., 2000). The application of tail bands and the process of tail atrophy did not appear to measurably influence the behavior of PPH in our study. Our behavioral observations for PPH agree with Eicher et al. (2000), although we did not find an increase in eating behavior in banded animals. This difference may be due to differences in feeding practices between studies. In our study, fresh feed was supplied once daily, which resulted in most animals wanting to eat during the same periods of time.

Cortisol is often used as an indicator of acute stress in animals. The methodology used to collect blood samples is important because stress induced by handling could result in a cortisol response that could mask potential treatment effects. It is unlikely that handling 


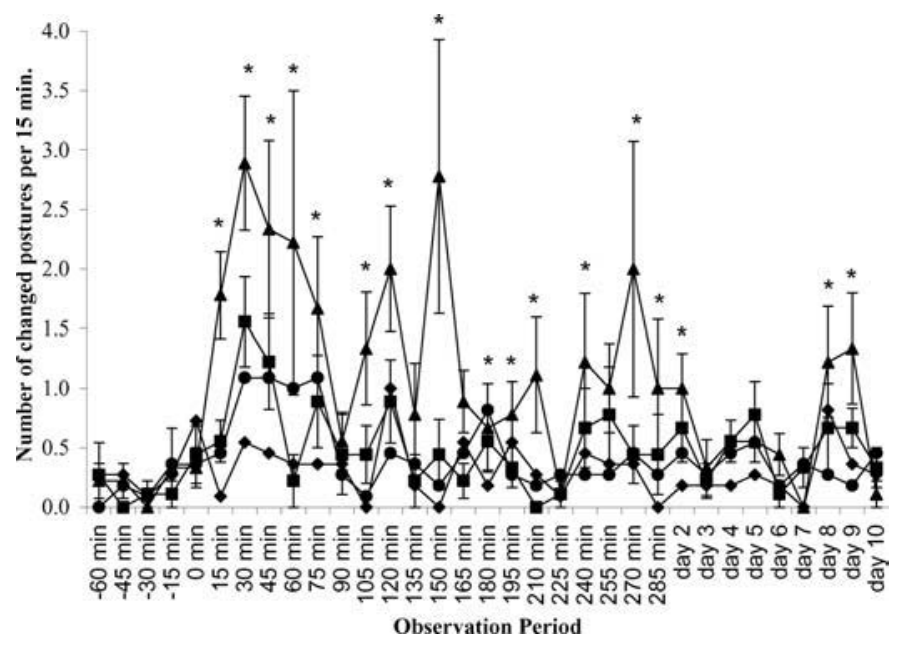

Figure 5. Number of changes in posture per 15-min period for preweaned calves by treatment and age. Legend: young docked calves $(\bullet)$, young control calves $(\bullet)$, old docked calves $(\boldsymbol{\Lambda})$, old control calves (घ). Contrast between old docked vs old control was significant $(P<$ $0.01)$. *Indicates time period when significant difference was detected.

adversely influenced the values we obtained because they were consistent with cortisol values reported previously using similar methodology (Coulon et al., 1998; Eicher et al., 2001; and Elvinger et al., 1992). Our values were also consistent with values collected using indwelling catheters in calves (Tom et al., 2002). The values of plasma cortisol obtained for the heifers in our study varied between animals and were virtually identical to previous reports that have studied tail docking (Eicher et al., 2000; Petrie et al., 1995; Tom et al., 2002). As others have observed, plasma cortisol values were not significantly influenced by treatment that the heifers received. Individual animal differences appeared to have the largest influence on plasma cortisol values. Throughout the study, one control animal demonstrated aversion to handling. Plasma cortisol values from this animal were consistently high. Reinemann et al. (1999) demonstrated that the process of hoof trimming would elicit a large increase in plasma cortisol values of adult dairy cattle. The values observed in that study ( 24.4 to $52.2 \mathrm{ng} / \mathrm{ml}$ ) were markedly higher than we observed, indicating that the process of tail docking using rubber rings produces less acute stress compared to hoof trimming.

The physiological response to stress typically includes leukocytosis, neutrophilia, lymphopenia, and eosinopenia (Jain, 1993). These characteristics were not demonstrated by leukograms obtained for any cows regardless of treatment. Eicher et al. (2000) noted a lymphocyte response to lidocaine, but likewise did not demonstrate a direct hematological response to the process of tail banding. In our study, the proportion of eosino- phils was increased in cows that received epidurals compared to other groups, but remained within normal limits. There was a significant increase in red blood counts and hematocrits for all groups over time, but these values were also within normal ranges and may have been related to impending parturition. Levels of neutrophils were slightly above the reference range for all groups, indicating that there may have been an immune response to a factor other than the application of tail bands, or perhaps a response to impending parturition (Ewing et al., 1999).

A range of 60 to 84 beats/min has been described as the preferred normal range of heartbeat of adult dairy cattle (Rebhun, 1995). Heart rates of the cattle in our study were within the limits for healthy cattle that have been recently handled, and there were no significant differences among groups that could be attributed to tail docking. Heart rates were lower in the beginning of the study when animals were handled more frequently and may have been more acclimated to human contact. Pain may result in tachycardia, but Molony and Kent (1997) discredit heart rate in lambs as a practical indication of pain due to many interfering variables, such as eating, exercise, and extraneous noises. It is likely that the heart rates of $\mathrm{PPH}$ in our study were also influenced by these factors.

Our study included short-term behavioral responses to tail banding in calves that were 1 to $6 \mathrm{wk}$ of age, but we were unable to collect additional data on the calves because of financial limitations. Tom et al. (2002) recorded few acute responses to tail docking in 7- to 17d-old calves but the calves did demonstrate increased tail grooming and a higher frequency of standing and lying on the day of banding. Calves that were 3 to 4 mo of age demonstrated tail shaking during the first 30 min after treatment (Petrie et al., 1995). Petrie et al. (1995) also noted vocalization for $90 \mathrm{~min}$ after application of rubber rings. In that study, the use of local anesthesia before docking inhibited all behavioral responses for approximately $2.5 \mathrm{~h}$. The authors concluded that tail docking using rubber rings elicited a behavioral response, but not enough to cause a significant difference in normal feeding and ruminating behaviors (Petrie et al., 1995). In our study, we observed significantly more restlessness and rear visualization in older calves that were docked compared to younger calves and older control calves, but the overall response to tail docking was minor.

An effect of age on behavioral responses to tail docking has been previously reported in lambs. Graham et al. (1997) compared behavioral and adrenal responses to tail docking in 3-wk-old lambs using three methods: 1) rubber rings, 2) crushing (burdizzo) combined with application of rubber rings, and 3) heat docking with an 
iron. They reported the greatest behavioral and adrenal response to tail docking when rubber rings were used. Kent et al. (1995) reported increased behaviors, such as foot stamping, abnormal posture, and restlessness, in animals docked and castrated with rubber rings in lambs 5 to $6 \mathrm{~d}$ of age. In contrast, Dinnis et al. (1997) reported that tail docking with rubber rings caused comparatively low levels of distress in lambs that were 45 to $55 \mathrm{~d}$ old.

In this study, we observed more restlessness in OPWC after application of the tail bands compared to the OPW control calves, YPW control calves, and YPW calves that received tail bands. Shutt (1988) reported significant distress in 3- to 6 -wk-old lambs that were docked using rubber rings, and a significant stress response (as measured by cortisol levels) to tail banding in 1- to 7-d-old lambs has been reported (Mellor and Murray, 1989).

In our study, no significant behavioral, immunological, or hormonal responses to tail banding or to the process of tail atrophy of PPH were observed. Tail banding had no significant effect on behavior of calves $\leq$ $21 \mathrm{~d}$ of age, whereas some behavioral differences in response to application of tail bands were demonstrated in calves 22 to $42 \mathrm{~d}$ of age. The behavioral response in the older calves demonstrates the need for additional research on potential interactions between age and behavioral effects of other management practices (such as dehorning, removal of supernumerary teats, etc.).

\section{REFERENCES}

Coulon, J. B., P. Pradel, T. Cochard, and B. Poutrel. 1998. Effect of extreme walking conditions for dairy cows on milk yield, chemical composition, and somatic cell count. J. Dairy Sci. 81:994-1003.

Dinnis, A. S., K. J. Stafford, D. J. Mellor, R. A. Bruce, and R. N. Ward. 1997. Acute cortisol responses of lambs castrated and docked using rubber rings with or without a castration clamp. Aust. Vet. J. 75:494-496.

Eicher, S. D., J. L. Morrow-Tesch, J. L. Albright, J. W. Dailey, C. R. Young, and L. H. Stanker. 2000. Tail-docking influences on behavioral, immunological, and endocrine responses in dairy heifers. J. Dairy Sci. 83:1456-1462.

Eicher, D. S., J. L. Morrow-Tesch, J. L. Albright, and R. E. Williams. 2001. Tail-docking alters fly numbers, fly-avoidance behaviors, and cleanliness, but not physiological measures. J. Dairy Sci. 84:1822-1828.

Elvinger, F., R. P. Natzke, and P. J. Hansen. 1992. Interactions of heat stress and bovine somatotropin affecting physiology and immunology of lactating cows. J. Dairy Sci. 75:449-462.
Ewing, S. A., D. C. Lay, and E. Von Borell. 1999. Farm Animal Well Being. Prentice Hall. Upper Saddle River, NJ.

Graham, M. J., J. E. Kent, and V. Molony. 1997. Effects of four analgesic treatments on the behavioral and cortisol responses of 3-week-old lambs to tail docking. Vet. J. 153:87-97.

Hemsworth, P. H., J. L. Barnett, L. Beveridge, and L. R. Matthews. 1995. The welfare of extensively managed dairy cattle: A review. Appl. Anim. Behav. Sci. 42:161-182.

Jain, N. C. 1993. Essentials of Veterinary Hematology. Lea and Febiger, Philadelphia, PA.

Johnson, A. P. 1991. Mastitis control without a slap in the face. Page 146 in Proc. 24th Annu. Conv. Bovine. Assoc. Am. Bov. Prac. Orlando, FL.

Kent, J. E., V. Molony, and I. S. Robertson. 1995. Comparison of the burdizzo and rubber ring methods for castrating and tail docking lambs. Vet. Rec. 136:192-196.

Matthews, L. R. 1996. Animal welfare and sustainability of production under extensive conditions: A non-EU perspective. Appl. Anim. Behav. Sci. 49:41-46.

McCrory, J. 1976. Do cow's tails help cause mastitis? J. Agric. 74:341.

Mellor, D. J., and L. Murray. 1989. Changes in the cortisol responses of lambs to tail docking, castration and ACTH injection during the first seven days after birth. Res. Vet. Sci. 46:392-395.

Molony, V., and J. E. Kent. 1997. Assessment of acute pain in farm animals using behavioral and physiological measurements. J. Anim. Sci. 75:266-272.

Petrie, N. J., K. J. Stafford, D. J. Mellor, R. A. Bruce, and R. N. Ward. 1995. The behavior of calves tail docked with a rubber ring used with or without local anesthesia. Proc. N.Z. Soc. Anim. Prod. 55:58-60.

Phipps, A. M., L. R. Matthews, and G. A. Verkerk. 1995. Tail docked dairy cattle: Fly induced behavior and adrenal responsiveness to ACTH. Proc. N.Z. Soc. Anim. Prod. 55:61-63.

Rebhun, W. C. 1995. Diseases of Dairy Cattle. Williams and Wilkins, Media, PA.

Reinemann, D. J., M. D. Rasmussen, L. G. Sheffield, M. C. Wiltbank, and S. D. LeMire, 1999. Dairy cow response to electrical environment: Part I. Comparison of behavioral to physiological responses; Part II. Comparison of treatments applied during milking. Report to the Minnesota Public Utilities Commission, June 30, 1999.

SAS User's Guide: Statistics, Version 8 Edition. 1999. SAS Inst., Inc., Cary, NC.

Schreiner, D. A., and P. L. Ruegg. 2002. Effects of tail docking on milk quality and cow cleanliness. J. Dairy Sci. 85:2513-2521.

Shutt, D. A., L. R. Fell, R. Connell, and A. K. Bell. 1988. Stress responses in lambs docked and castrated surgically or by the application of rubber rings. Aust. Vet. J. 65:5-7.

Stull C. L., M. A. Payne, S. L. Berry, and P. J. Hullinger. 2002. Evaluation of the scientific justification for tail docking in dairy cattle. J. Am. Vet. Med. Assoc., 220:1298-1303.

Swanson, J. C. 1995. Farm animal well-being and intensive production systems. J. Anim. Sci. 73:2744-2751.

Tom, E. M., J. Rushen, I. J. H. Duncan, and A. M. de Passille. 2002. Behavioural, health and cortisol responses of young calves to tail docking using a rubber ring or docking iron. Can. J. Anim. Sci. 82:1-9.

Tucker, C. B., D. Fraser, and D. M. Weary. 2001. Tail docking dairy cattle: Effects on cow cleanliness and udder health. J. Dairy Sci. 84:84-87. 